\title{
The Role of Educational Awareness of Biotechnology Products and Services in Senior Secondary Schools in Enugu East Local Government Area
}

\author{
Chidobi Roseline Unoma (Ph.D), Menkiti, B.U (Ph.D)² \\ ${ }^{1}$ Department of Educational Management, Enugu State University of Science and Technology, Enugu, Nigeria \\ West Africa \\ ${ }^{2}$ Godfrey Okoye University Enugu, Nigeria
}

\begin{abstract}
Both literature and experience suggest that there has been little or no attention paid to biotechnology in Nigerian education. There is no organized curriculum on biotechnology among the subjects taught in secondary schools in Enugu education zone. This study examined whether students in secondary schools in Enugu east local government area are aware of biotechnology products and services, the role of educational awareness of biotechnology, and the strategies to be employed to ensure awareness of this important area. Data were collected using a 25-item questionnaire, administered to 300 SSI and SS2 science students and 50 science teachers in the area. Results were analyzed using mean and standard deviations and significance determined by means of t-test of difference in mean. The results showed that senior secondary science students are highly unaware of biotechnology products and service. The proposed strategies for increasing awareness rated highly. The researchers recommended that the senior secondary science curriculum be modified to include units on biotechnology.
\end{abstract}

Keywords- Biotechnology services, Biotechnology Products, Educational Awareness, DNA.

\section{INTRODUCTION}

It has been noted that life on earth has existed for more than 3.7 billion years (Wikipedia 2009) Human have been part of that existence, which they have been able to sustain all through the ages, through the utilization of other, lesser organisms. This utilization, which started with the early humans has continued and has helped them to survive. According to guest (1980), the humans started as wanderers, a hunters, later as shepherds and lastly as farmers. Settled community living emerged; with the emergence of

$\underline{\text { www.ijeab.com }}$ community living, life became progressively more stable, more comfortable and more qualitative. This situation gave humans more opportunity to explore their environment and gradually arrived at the early stage of civilization. Guest (1980) opined that for millions of years, numbers advances in science and arts, through crude at the time, have continued to improve human existence.

Eventually, the emergence of formal education brought about quality development and a more sophisticated advancement in various fields, especially in science education. Every formal education system of any nation all over the world aims at equipping its citizens, including the youths, with the knowledge and skill required for them to develop the spirit of enquiry and curiosity. (The knowledge so gained will provide them with skills that will help them to be critical, to solve their problems and to cope with an increasing scientific and technological society). Nigeria is not an exception in this direction. For any nation, including Nigeria, to be developed, there must be very strong knowledge base regarding technology, which is the application of scientific knowledge to various endeavors in order to enhance life. An area of science and technology that has developed rapidly in recent years is the field of biotechnology. Biology is one of those fields of study that technology has affected and this field is known as biotechnology.

\section{BACKGROUND OF THE STUDY AND STATEMENT OF THE PROBLEM}

From the beginning of creation, humans were mandated to dominate other creatures. In carrying out this function they have tried and are still trying to conquer the world using other, lesser organisms. Part of the quest for this dominion over all created things is the result of the improvement of the 
natural capabilities of microorganisms and using them in new processes of production and the further discovery of new microorganisms with new capabilities (Singh, Gupta and Gupta 2006). In trying to achieve this, humans have to utilize the field of biotechnology, which involves the use of living organisms and bioprocesses to produce goods and services for the benefit of mankind.

There has, however, been little or no information available through education about these biotechnology products and services. There was no organized curriculum on biotechnology among the list of subjects taught in secondary schools in Enugu State, and this may be part of the reason why students are left in the dark as to what constitutes biotechnology products and services. This situation therefore creates a gap, since there is a scarcity of available studies in respect to this topic. The few that are available have not dealt with educational awareness. It is in order to close this gap that this study becomes necessary. Biotechnology products and services like pesticides, deozyribonucleicacid (DNA) tests, tomato, tobacco, BT corn, insulin, enzymes, antibiotics, polished rice, Fertilizers are used daily by the students without actually identifying them as such, without any knowledge of the contents of the products and the processes involved.

The problem of this study therefore focuses on the possibility of creating educational awareness of biotechnology products and services, among teachers and students in secondary schools.

\section{PURPOSE OF THE STUDY}

The general purpose of the study was to find out the role of educational awareness of biotechnology products and services among Senior Secondary Schools Students in Enugu East Local Government Area. Specifically the purpose was:

1. To determine the extent that senior secondary students are aware of biotechnology products and services.

2. To find out the extent senior secondary school students were aware of the usefulness of the biotechnology products and services.

3. To examine the role of educational awareness on biotechnology products and services as perceived by students.

4. To examine the role of educational awareness on biotechnology products and services as perceived by teachers.

5. To identify the strategies for implementing biotechnology education.

\section{LITERATURE REVIEW}

The review of literature is done under the following subheadings:

- Concepts of biotechnology

- Biotechnology products and services

- The usefulness of biotechnology products and services

- The role f educational awareness of biotechnology products and services.

- $\quad$ Strategies for providing educational awareness.

\section{Concepts of Biotechnology}

Drubbel (2003) defines technology as the application of science to practical human ends, especially in increased productivity, availability of leisure and to improve the quality of life. Technology includes development since ancient times and is applied in every sphere of human activity - in agriculture, electricity, medicine, biology and drugs, among others. The term biotechnology is derived by the combination of biology and technology. It is the use of microorganisms or biological substances to perform specific industrial functions or manufacturing processes. For the United Nations (1992), biotechnology is defined as any technological application thereof for specific use. Various definitions of biotechnology have different approached, content and emphases given the vast area of the subject being discussed. The common denominator for the approach, content and emphasis for each of the definitions lies in - (a) utilization of biological entities (which includes microorganisms and cells living and dead) and their components and constituents (such as enzymes) in such a way that (b) some product or services is generated to enhance human welfare (Wikipedia (2009).

\section{Biotechnology Products and Services}

Biotechnology products and services are those goods produced through the application of technology using microorganisms and cells, both living and dead, and the services that can be rendered using those products. The products range from those produced before 6000BC to the ones being produced in this $21^{\text {st }}$ century. According to Singh, Gupta and Gupta (2006), wine and beer and leavened bread were produced between $6000 \mathrm{BC}$ and $4000 \mathrm{BC}$ respectively; copper mining with the aid of microbes around 1670 AD. Biotechnology has applications in four major industrial areas (A) medical, (b) crop production and agriculture and the use of crops and other products, (c) the manufacture of organic products, for example beer and milk products, (d) recycling, waste treatment, clean-up of sites contaminated by industrial activities (bioremediation), and also (e) the production of biological weapons. Wikipedia (2009) enumerated five branches of biotechnology: (a) green biotechnology, which 
is applied to agricultural processes; (b) red biotechnology, applied to medical processes; (c) white biotechnology, known as industrial biotechnology, applied to industrial processes; (d) bioinformatics, an interdisciplinary field which forms a key component in the biotechnology, which involves marine and aquatic application of biotechnology.

\section{The Usefulness of Products and Services}

It is noted that the uses of biotechnology products and services are many and varied. For instance, red biotechnology is applied to medical processes in which some organisms are designed to produce antibiotics, penicillin, and the engineering of genetic cures through genetic manipulations.

Green Biotechnology: Is applied to agriculture and has resulted in the following developments: selection and demonstration of plants via micro propagation, designing of transgenic plants to grow under a specific environment in the presence (or absence) of chemicals, and the engineering of a plant to express a pesticide. Examples of these are BT corn, cassava, rice, wine, beer, soy milk, pito burukutu.

White Biotechnology: Sometimes known as industrial biotechnology, is applied to industrial processes. Organisms are designed to produce useful chemicals, such as the use of enzymes as industrial catalysts to either produce valuable chemicals or to destroy hazardous polluting chemicals.

\section{The Role of Educational Awareness}

Education system has the major aim of equipping young people with knowledge, problem-solving skills and values to cope with an increasingly technological society (Dawson and Christiana, 2006). One of the essential elements of science education is to help students have a deeper understanding of the world in which they live (Goodrum, 2001, p. 183). There is the need, therefore, to acquire scientific literacy in science education so that the young people do not simply take in any information but question claims in terms of scientific matters. This will enable students to make informed scientific decisions and choices about their environment, their own health and well-being (Goodrum, 2001, p. 183).

Educational awareness will be useful in that, according to Lock and Miles (1995, p. 185), students and the public will have better understanding of issues regarding biotechnology so that they can differentiate biotechnology products from ones produced though other means; their reactions (if any) to the body. It is important that educational awareness be created for students in respect to biotechnology products and services. This will enable them to distinguish between genetically modified foods and those produced through selective breeding. For Millar (1996, p.184), it is becoming increasingly evident that student need to be more knowledgeable about the social, ethical and economic implications surrounding areas such as genetic engineering, cloning, genetically modified foods and other aspects of biotechnology. As a result of the impact of biotechnology on human health, agriculture and the environment, it is important that secondary school students have sufficient scientific background in genetics, cell biology and awareness of the associated risks and benefits so that they can make informed decisions (Millar, 1996, p.184). With this awareness, senior secondary school students would be able to have well-informed opinions about the risks and benefits associated with biotechnology products and services.

\section{Strategies for Implementing Biotechnology Education}

Strategies are the means for acquiring skills in managing any affair (Hornby 1981 ED). Every venture that one embarks on must have to be managed in such a way that the set objectives are achieved. For the management to be effectively undertaken, some strategies must be mapped out for proper implementation. For biotechnology educational awareness to be properly created, the following strategies must be looked into.

First and foremost, biotechnology should be incorporated into the existing biology curriculum and developed for senior secondary schools, which hitherto has not been the case. Millar (1996, p.184) advocated designing such a science programme curriculum for students of secondary schools in Austria. The same approach is being advocated and evaluated to make usher that they are adequate for teaching. Both formal and non-formal school programmes may be part of the strategies that will be employed. The formal school programme presents very few challenges, because the students are already in secondary schools. In the case of nonformal school programme, many challenges may be experienced, since the targets are secondary school drop-out. Gunter (1998, p.184) advocated the formal school programme as the best strategy. Teachers who are experts and specialists in all areas of biotechnology should be recruited. Proper incentives have to be given to the specialist teachers so that they will be dedicated to teaching the students. Mass Media, both print and electronic, will prove useful and handy and so should be made available to secondary schools in Enugu East Local Government Areas. In effect, there should be TV and radio teaching programmes, discussions, demonstrations and documentaries. There should also be biotechnology articles in newspapers and magazines. One strategy is the use of excursions to industries that produce biotechnology goods and services. Projects can be undertaken in the area of biotechnology. Students are expected to start and finish the projects under the guidance of the particular teachers responsible for the students. Another is to provide well-equipped biotechnology 
laboratories in each of the secondary schools offering biology. This will enable the students to carry out experiments for better understanding of the subject. Biotechnology education in secondary school is necessary to create products and services.

This paper was based on the role of educational awareness of biotechnology products and services in Senior Secondary Schools in Enugu East Local Government Area.

\section{Scope of the Study}

The study covered senior secondary schools in Enugu East Local Government Area. In terms of content, the study was on the role of educational awareness of biotechnology products and services among senior secondary school students.

\section{RESEARCH QUESTIONS}

1. To what extent are the Senior Secondary School Students in Enugu East Local Government Area aware of biotechnology products and services?

2. To what extent are Senior Secondary School Student aware of the usefulness of biotechnology products and services?

3. What is the role of educational awareness of biotechnological products and services in respect to Senior Secondary School Students in Enugu East Local Government Area?

4. What is the role of educational awareness of biotechnological products and services in respect to teachers in Enugu East Local Government Area?

5. What are the best available strategies for implementing biotechnology education in Senior Secondary School Students in Enugu East Local Government Area?

\section{Hypotheses}

$\mathrm{H}_{01} \quad$ There is no significant difference between the means responses of Teachers and science students on the role of educational awareness on biotechnology products and services.

$\mathrm{H}_{02}$ There is no significant difference in the means responses of SSI and SSII students on the role of educational awareness on biotechnology products and services.

\section{METHODOLOGY}

The study adopted a descriptive survey design. For Nworgu (1991), a survey is a study where peculiar characteristics of a known or identified population are studied through a sample that is deemed to be representative of the population. As a result of this, the convenient sampling technique was used to select 5 out of twenty secondary schools in Enugu East Local Government area. Stratified sampling procedures were then used to select 30 SSI and 30 SS2 science students and 10 science teachers from each of the five secondary schools sampled, giving a total of 350 sample size of 150 SS1 science students, 150 SS2 science students and 50 science teachers. The instrument used for data collection was a structured questionnaire consisting of 25-tiems, with a 4point Likert rating scale, weighted 4, 3, 2, and 1 respectively. In order to collect data for answering research questions 1 and 2, the response categories were Very High Extent, High Extent, Low Extent and Very Low Extent. For research questions 3 and 4 the response categories were Strongly Agreed, Agreed, Disagreed and Strongly Disagreed.

The instrument was face-validated by experts in Measurement and Evaluation at Enugu State University of Science and Technology and by lecturers in the Faculty of Natural and Applied Sciences, Godfrey Okoye University Enugu. 300 copies of the questionnaire were distributed to students and 50 to teachers. The researchers, with the help of five trained research assistants, did the distribution. All the 350 copies were dully completed and returned, giving a $100 \%$ rate of return.

\section{Method of Data Analysis}

The mean and standard deviation were used to answer the four research questions while a t-test of difference in means was used to test the two null hypotheses. A mean value of 2.5 was considered as the mid-point for acceptance. The decision rule for each hypothesis is non-acceptance of the $\mathrm{H}_{0}$ if the calculated $\mathrm{T}$ is greater than the tabulated $\mathrm{T}$ and acceptance of the hypotheses $\mathrm{H}_{0}$ if the calculated $\mathrm{T}$ is less than the tabulated T. 


\section{RESULTS}

Research Question 1: To what extent are the Senior Secondary School Students in Enugu East Local Government Area aware of biotechnology products and services?

Table.1: The extent of student's awareness of biotechnology products and services.

\begin{tabular}{|c|c|c|c|c|c|c|c|c|c|}
\hline \multirow{2}{*}{\multicolumn{2}{|c|}{\begin{tabular}{l|l} 
S/N & ITEMS \\
The extent of student's awareness of \\
biotechnology products and services.
\end{tabular}}} & \multirow{2}{*}{ VHE } & \multirow[t]{2}{*}{ HE } & \multirow[t]{2}{*}{$\mathbf{L E}$} & \multirow[t]{2}{*}{ VLE } & \multirow[t]{2}{*}{$\mathbf{N}$} & \multirow[t]{2}{*}{ II } & \multirow[t]{2}{*}{ SD } & \multirow[t]{2}{*}{ DECISION } \\
\hline & & & & & & & & & \\
\hline 1 & $\begin{array}{l}\text { Agriculture produces and services } \\
\text { (green biotechnology products and } \\
\text { services) }\end{array}$ & 20 & 30 & 200 & 100 & 350 & 1.9 & 0.77 & Disagree \\
\hline 2 & $\begin{array}{l}\text { medical products and services (white } \\
\text { biotechnology products) }\end{array}$ & 30 & 35 & 210 & 75 & 350 & 2.05 & 0.81 & Disagree \\
\hline 3 & marine products and services & 10 & 20 & 205 & 115 & 350 & 1.8 & 0.71 & Disagree \\
\hline 4 & industrial products and services & 40 & 50 & 215 & 45 & 350 & 2.2 & 0.82 & Disagree \\
\hline 5 & $\begin{array}{l}\text { Genetic engineering products and } \\
\text { services }\end{array}$ & 5 & 10 & 205 & 130 & 350 & 1.7 & 0.60 & Disagree \\
\hline & Grand mean & & & & & & 1.9 & & Disagree \\
\hline
\end{tabular}

Data presented in table 1 show that 5 items are responded to by both science teachers and students to a very low extent with the following mean scores: 1.9, 2.05, 1.8, 2.2 and 1.7 respectively. This reveals that secondary school students are not so much aware of biotechnology products and services; the grand mean score depicts the same results.

Research question 2: To what extent are Senior Secondary School Student aware of the usefulness of biotechnology products and services?

Table.2: The extent which the senior secondary schools are aware of the usefulness of biotechnology products and services in the productions of:

\begin{tabular}{|l|l|l|l|l|l|l|l|l|l|}
\hline S/N & ITEMS & VHE & HE & LE & VLE & N & II & SD & DECISION \\
\hline $\begin{array}{l}\text { The extent which the senior secondary } \\
\text { schools are aware of the usefulness of } \\
\text { biotechnology products and services in } \\
\text { the productions of: }\end{array}$ & & & & & & & & \\
\hline $\mathbf{6}$ & $\begin{array}{l}\text { Drugs immunization kit (vaccine), } \\
\text { insulin, diagnostic kit, DNA, drips }\end{array}$ & 60 & 145 & 100 & 45 & 350 & 2.6 & 0.91 & Agree \\
\hline $\mathbf{7}$ & $\begin{array}{l}\text { BT-corn, soy-milk, wine, beer, } \\
\text { tomatoes, tobacco, rise, cassava, } \\
\text { cheese, bread, milk }\end{array}$ & 150 & 98 & 52 & 350 & 2.6 & 0.91 & Agree \\
\hline $\mathbf{8}$ & $\begin{array}{l}\text { Enzymes, amino acids, vitamins, } \\
\text { nucleoxide }\end{array}$ & 10 & 40 & 200 & 100 & 350 & 1.8 & 0.71 & Disagree \\
\hline $\mathbf{9}$ & $\begin{array}{l}\text { Chemicals of all sorts-butanol, } \\
\text { organic acids, alcohol, acetone, etc }\end{array}$ & 25 & 30 & 195 & 100 & 350 & 0.9 & 0.82 & Disagree \\
\hline $\mathbf{1 0}$ & $\begin{array}{l}\text { Chicken, goats, cows, pigs, mice, } \\
\text { processed fish }\end{array}$ & 100 & 10 & 99 & 50 & 350 & 2.7 & 1.03 & Agree \\
\hline $\mathbf{1 1}$ & \begin{tabular}{l} 
DDT, camphor, xylene, scanning kit \\
\hline
\end{tabular} & 20 & 30 & 200 & 100 & 350 & 1.9 & 0.77 & Disagree \\
\hline
\end{tabular}

Data presented in table 2 reveal that items in numbers, 6, 7, and 10 have positive mean scores of 2.6, 2.6 and 2.7 respectively, showing that the students are aware of the usefulness of the items in serial numbers 6, 7, and 10. Items in numbers 8,9 and 11 with the mean ratings of 1.9, 1.9 and 1.9 respectively are responded a very low extent to by the science teachers and students. This on the other hand shows that the respondents have very little awareness of usefulness of biotechnology products and services. The 
grand mean of 2.3 shows that students and the science teachers have very low unawareness of the usefulness of biotechnology products and services.

Research Question 3: What is the role of educational awareness of biotechnological products and services among Senior Secondary School Students and science teachers?

Table.3: The role of educational awareness of biotechnological products and services among Senior Secondary School Students - science students' response.

\begin{tabular}{|c|c|c|c|c|c|c|c|c|c|}
\hline $\mathbf{S} / \mathbf{N}$ & ITEMS & VHE & HE & LE & VLE & $\mathbf{N}$ & II & SD & DECISION \\
\hline \multicolumn{10}{|c|}{$\begin{array}{l}\text { State the level of your agreement on the } \\
\text { role of educational awareness on } \\
\text { biotechnology products and services. Such } \\
\text { educational awareness will enable science } \\
\text { students and science teachers to: }\end{array}$} \\
\hline 12 & $\begin{array}{l}\text { Deepen understanding of } \\
\text { biotechnology influence in the } \\
\text { environment/products and services }\end{array}$ & 100 & 150 & 35 & 15 & 300 & 3.1 & 0.74 & Agreed \\
\hline 13 & $\begin{array}{l}\text { Acquire scientific literacy that will } \\
\text { help students acquire knowledge of } \\
\text { biotechnology products }\end{array}$ & 80 & 100 & 90 & 30 & 300 & 2.8 & 0.89 & Agreed \\
\hline 14 & $\begin{array}{l}\text { Help them to make informed } \\
\text { scientific decision and choices of } \\
\text { biotechnology products and services }\end{array}$ & 90 & 140 & 50 & 20 & 300 & 3.0 & 0.8 & Agreed \\
\hline 15 & $\begin{array}{l}\text { Become aware of biotechnology } \\
\text { products and services and to } \\
\text { differentiate them from others } \\
\text { produced through other means }\end{array}$ & 60 & 140 & 80 & 20 & 300 & 2.8 & 0.68 & Agreed \\
\hline 16 & $\begin{array}{l}\text { Become knowledgeable about } \\
\text { ethical, social and economic } \\
\text { implications of cloning and other } \\
\text { biotechnology products and services }\end{array}$ & 60 & 140 & 80 & 20 & 300 & 2.8 & 0.68 & Agreed \\
\hline 17 & $\begin{array}{l}\text { Have knowledge and awareness of } \\
\text { associated risks and benefits of these } \\
\text { products and services }\end{array}$ & 120 & 170 & 6 & 4 & 300 & 3.3 & 0.56 & Agreed \\
\hline & Grand mean & & & & & & 3.05 & & Agreed \\
\hline
\end{tabular}

Data presented in table 3 show that all the items are positively responded to with mean scores of between $2.8-3.3$ and a grand mean score of 3.05, showing that the respondents agree with all the items. This shows too that educational awareness would play a major role in assisting secondary school science students and their science teachers become aware of biotechnology products and services and their associated risks and benefits. 
Research Question 4: What is the role of educational awareness of biotechnological products and services in respect of science

Teachers responses?

Table.4: The role of educational awareness of biotechnological products and services among senior secondary science students science teachers' response.

\begin{tabular}{|c|c|c|c|c|c|c|c|c|c|}
\hline \multirow{2}{*}{\multicolumn{2}{|c|}{$\begin{array}{l}\text { S/N } \mathrm{N} \text { ITEMS } \\
\text { State the level of your agreement on the } \\
\text { role of educational awareness on } \\
\text { biotechnology products and services. Such } \\
\text { educational awareness will enable science } \\
\text { students and science teachers to: }\end{array}$}} & VHE & HE & LE & VLE & $\mathbf{N}$ & II & SD & DECISION \\
\hline & & & & & & & & & \\
\hline 12 & $\begin{array}{l}\text { Deepen understanding of } \\
\text { biotechnology influence in the } \\
\text { environment/products and services }\end{array}$ & 15 & 25 & 5 & 5 & 50 & 3.0 & 0.74 & Agreed \\
\hline 13 & $\begin{array}{l}\text { Acquire scientific literacy that will } \\
\text { help students acquire knowledge of } \\
\text { biotechnology products }\end{array}$ & 12 & 26 & 7 & 5 & 50 & 2.9 & 0.89 & Agreed \\
\hline 14 & $\begin{array}{l}\text { Help them to make informed } \\
\text { scientific decision and choices of } \\
\text { biotechnology products and services }\end{array}$ & 13 & 25 & 0 & 10 & 50 & 2.9 & 0.8 & Agreed \\
\hline 15 & $\begin{array}{l}\text { Become aware of biotechnology } \\
\text { products and services and to } \\
\text { differentiate them from others } \\
\text { produced through other means }\end{array}$ & 20 & 20 & 0 & 10 & 50 & 3.0 & .53 & Agreed \\
\hline 16 & $\begin{array}{l}\text { Become knowledgeable about } \\
\text { ethical, social and economic } \\
\text { implications of cloning and other } \\
\text { biotechnology products and services }\end{array}$ & 20 & 25 & 0 & 3 & 50 & 3.2 & 0.68 & Agreed \\
\hline 17 & $\begin{array}{l}\text { Have knowledge and awareness of } \\
\text { associated risks and benefits of these } \\
\text { products and services }\end{array}$ & 15 & 25 & 5 & 5 & 50 & 3.0 & 0.56 & Agreed \\
\hline & Grand mean & & & & & & 3.0 & & Agreed \\
\hline
\end{tabular}

In the same vein the response of teachers as shown in the above table for items $12-17$ were positive on the role of educational awareness in assisting secondary school students know about biotechnology products and services, even the associated risks and benefits.

Research Question 5: What are the strategies for implementing biotechnology education in Senior Secondary School in Enugu East Local Government Area?

Table.5a: Strategies for implementing biotechnology education - students' response.

\begin{tabular}{|c|c|c|c|c|c|c|c|c|c|}
\hline $\mathbf{S} / \mathbf{N}$ & ITEMS & VHE & HE & LE & VLE & $\mathbf{N}$ & II & SD & DECISION \\
\hline 18 & $\begin{array}{l}\text { Designing and development of } \\
\text { biotechnology as a tool for teaching } \\
\text { biology and agriculture education in the } \\
\text { senior secondary schools and incorporated } \\
\text { into biology curriculum }\end{array}$ & 60 & 200 & 30 & 10 & 300 & 3.02 & 0.61 & Agreed \\
\hline
\end{tabular}




\begin{tabular}{|c|c|c|c|c|c|c|c|c|c|}
\hline 19 & $\begin{array}{l}\text { Non-formal education for out-of-school } \\
\text { youths }\end{array}$ & 55 & 100 & 90 & 45 & 300 & 2.55 & 0.90 & Agreed \\
\hline 20 & $\begin{array}{l}\text { Well trained biotechnology teachers to be } \\
\text { provided }\end{array}$ & 100 & 160 & 30 & 10 & 300 & 3.05 & 0.70 & Agreed \\
\hline 21 & $\begin{array}{l}\text { Well articulated incentives to be given to } \\
\text { the teachers and those detailed to teach the } \\
\text { students on special arrangement }\end{array}$ & 101 & 149 & 25 & 25 & 300 & 3.07 & 0.80 & Agreed \\
\hline 22 & & 80 & 150 & 50 & 20 & 300 & 2.97 & 0.77 & Agreed \\
\hline 23 & $\begin{array}{l}\text { use of excursions and other programmes } \\
\text { such as biotechnology workshops, } \\
\text { seminars for both science students and } \\
\text { teachers }\end{array}$ & 50 & 110 & 90 & 50 & 300 & 2.6 & 0.90 & Agree \\
\hline 24 & $\begin{array}{l}\text { Taking on biotechnology projects when } \\
\text { appropriate or necessary }\end{array}$ & 65 & 135 & 60 & 40 & 300 & 2.8 & 0.88 & Agreed \\
\hline 25 & $\begin{array}{l}\text { Availability of well equipped } \\
\text { biotechnology laboratories and centers for } \\
\text { experiments }\end{array}$ & 110 & 170 & 20 & 10 & 300 & 3.3 & 0.68 & Agreed \\
\hline & Grand mean & & & & & & 2.9 & & Agreed \\
\hline
\end{tabular}

In table 5a, it is seen that data on the strategies for implementing educational awareness of biotechnology products and services have the mean scores of 2.02, 2.5, 3.05, 3.07, 2.97, 2.8, and 3.3 respectively with a grand mean of 2.9. This shows that students responded positively meaning that the strategies can effectively by applied at the appropriate time.

Table.5b: Strategies for implementing biotechnology education - teachers' response.

\begin{tabular}{|l|l|l|l|l|l|l|l|l|l|}
\hline S/N & ITEMS & VHE & HE & LE & VLE & N & II & SD & DECISION \\
\hline $\mathbf{1 8}$ & $\begin{array}{l}\text { Designing and development of } \\
\text { biotechnology as a tool for teaching } \\
\text { biology and agriculture education in the } \\
\text { senior secondary schools and } \\
\text { incorporated into biology curriculum }\end{array}$ & 10 & 30 & 5 & 5 & 50 & 2.9 & 0.61 & Agreed \\
\hline $\mathbf{1 9}$ & $\begin{array}{l}\text { Non-formal education for out-of-school } \\
\text { youths }\end{array}$ & 8 & 25 & 5 & 12 & 50 & 2.6 & 0.90 & Agreed \\
\hline $\mathbf{2 0}$ & $\begin{array}{l}\text { Well trained biotechnology teachers to } \\
\text { be provided }\end{array}$ & 20 & 25 & 2 & 3 & 50 & 3.05 & 0.70 & Agreed \\
\hline $\mathbf{2 1}$ & $\begin{array}{l}\text { Well articulated incentives to be given to } \\
\text { the teachers and those detailed to teach } \\
\text { the students on special arrangement }\end{array}$ & 10 & 20 & 10 & 10 & 50 & 3.07 & 0.80 & Agreed \\
\hline $\mathbf{2 2}$ & $\begin{array}{l}\text { print and electronic media-television, } \\
\text { radio, video tapes, teaching programmes } \\
- \text { as well as written articles in } \\
\text { newspapers and magazines made } \\
\text { available to senior secondary schools }\end{array}$ & 5 & 36 & 5 & 4 & 50 & 2.97 & 0.77 & Agreed \\
\hline $\mathbf{2 3}$ & $\begin{array}{l}\text { use of excursions and other programmes } \\
\text { such as biotechnology workshops, } \\
\text { seminars for both science students and } \\
\text { teachers }\end{array}$ & 6 & 28 & 16 & 0 & 50 & 2.8 & 0.90 & Agreed \\
\hline $\mathbf{2 4}$ & $\begin{array}{l}\text { Taking on biotechnology projects when } \\
\text { appropriate or necessary }\end{array}$ & 7 & 20 & 20 & 3 & 50 & 2.7 & 0.88 & Agreed \\
\hline
\end{tabular}




\begin{tabular}{|l|l|l|l|l|l|l|l|l|l|}
\hline 25 & $\begin{array}{l}\text { Availability of well equipped } \\
\text { biotechnology laboratories and centers } \\
\text { for experiments }\end{array}$ & 10 & 20 & 5 & 5 & 50 & 3.1 & 0.68 & Agreed \\
\hline & Grand mean & & & & & & 2.9 & & Agreed \\
\hline
\end{tabular}

In table $5 \mathrm{~b}$, showing data on response of science teachers in the strategies for implementing educational awareness of biotechnology products and services, the items have the mean scores of 2.9, 2.6, 3.2, 2.6, 3.0, 2.8, 2.7 and 3.1 respectively with a grand mean of 2.9. This indicates that teachers responded positively on the effectiveness of the strategies suggested.

$\mathrm{H}_{01} \quad$ There is no significant difference between the means responses of

Science teachers and science students (SS1 and SS2) on the role of educational awareness of biotechnology products and services.

Table.6: The difference in the mean responses of science teachers and science students in SS1 on the role of educational awareness of biotechnology products and services.

\begin{tabular}{|c|c|c|c|c|c|c|c|c|}
\hline Respondents & SA & $\mathbf{A}$ & D & SD & Total & T-table & T-cal & Decision \\
\hline Science teachers & 15 & 25 & 5 & 5 & 50 & \multirow[b]{3}{*}{-2.31} & \multirow[b]{3}{*}{0.56} & \multirow[b]{3}{*}{ Accept } \\
\hline Science students SS1 & 40 & 105 & 3 & 2 & 150 & & & \\
\hline Total & 55 & 130 & 8 & 7 & 200 & & & \\
\hline
\end{tabular}

The result shows that $\mathrm{H}_{01}$ failed to reject that there is no significant difference between the responses of science teachers and SS 1 science students on the role of educational awareness on biotechnology products and services in Enugu East Local Government area, since the T-cal $0.56<$ T-table 2.31 .

$\mathrm{H}_{02}$ There is no significant difference in the means responses of science teachers and SSII on the role of educational awareness on biotechnology products and services.

Table 7: The difference in the mean responses of science teachers and science students in SS 2 on the role of educational awareness on biotechnology products and services.

\begin{tabular}{|l|l|l|l|l|l|l|l|l|}
\hline Respondents & SA & A & D & SD & Total & T-table & T-cal & Decision \\
\hline Science teachers & 15 & 25 & 5 & 5 & 50 & & & \\
\cline { 1 - 5 } $\begin{array}{l}\text { Science students } \\
\text { SS11 }\end{array}$ & 40 & 116 & 4 & 0 & 150 & & \multirow{2}{*}{ Accept } \\
\cline { 1 - 5 } Total & 45 & 141 & 9 & 5 & 200 & & 0.11 \\
\hline
\end{tabular}

$\mathrm{H}_{02}$ is accepted that there is no significant difference between the mean scores of science teachers and SS II science students on the role of educational awareness on biotechnology products and services Enugu East Local Government area, since the T-cal -0.11 < T-table 2.31 .

\section{DISCUSSION}

In view of the response from teachers and students, the study revealed that senior secondary school science students and science teachers are not very aware of biotechnology products and services. Therefore, if biotechnology inputs and elements (courses) are included in the senior secondary school biology curriculum, the students will become aware of biotechnology products and services. The study also shows that the respondents are only partially aware of the usefulness of biotechnology products and services. For example, Singh (2006) says that white biotechnology is applied to industrial processes using organisms which are designed to produce useful chemicals. In order words, it is necessary to make science students of senior secondary school educationally aware of these biotechnology products and services.

The results in table 3 and 4 giving the response of student and teachers reveals that educational awareness of biotechnology products and services play a significant role. The above findings are in line with what Dawson and Christian (2006) said, that education system has the major role of equipping young people with knowledge, problem-solving skills and 
values to cope with an increasingly technological society. In the same vain Goodrum (2006) opined that one the essential elements of science education is to help students have a deeper understanding of the world in which they life. In sum, educational awareness will be useful in that, according to Lock and Miles (1995), the students and the public will have better understanding of issues regarding biotechnology so that they can differentiate between biotechnology products and services and others produced through other means.

In the study, the findings in table $5 \mathrm{a}$ and $5 \mathrm{~b}$, the responses of teachers and students, shows that for biotechnology educational awareness to be created properly, all the strategies mapped out should be applied. The findings agree with what Miller (1996) advocated for the design of the science curriculum for students of secondary schools in Australia.

In table $5 \mathrm{a}$ and $5 \mathrm{~b}$, there is a great similarity between the science teachers' responses and student's responses to biotechnological products and services.

Finally, the results in tables 6 and 7 shows that there is no significant difference between the mean responses of the science teachers and both SSI and SSII science students on the role of educational awareness on biotechnology products and services.

\section{Conclusion and Recommendations}

The results of the study support the following recommendations:

1. Teachers who majored in biotechnology will be employed in the secondary schools in Enugu Education Zone to teach in the senior secondary schools, so that the students will have the knowledge of biotechnology and its products and services.

2. Well-equipped biotechnology laboratories and centers, will be established in the secondary schools for us in teaching. Laboratories will also be provided for students' research and experiences and centers for teachers majored in biology and agriculture for practical use and application.

3. Biotechnology should be critically considered as a tool for teaching biology and agriculture. Therefore, some elements of biotechnology should be incorporated into biology and agriculture science curriculum.

4. Both print and electronic media and relevant instructional materials in biotechnology should be made available to senior secondary schools in Enugu for appropriate courses.
5. Excursions to institutions that produce biotechnology goods and services should be arranged for science students from time to time.

6. Government should provide proper financial incentives to those who major in teach biotechnology. There should also be biotechnology workshops and seminars for biotechnology teachers. Given existing constraints an orientation programme would be ideal for such teachers.

\section{REFERENCES}

[1] Dawson, V. and Soames, C. (2006). The Effect of biotechnology Education on Australian High School Students' Understandings and Attitudes about Biotechnology Processes. Research in Science and Technology Education, 24(2), pp.183-198.

[2] Drubbel, B. (2003) (Ed). 21 $1^{\text {st }}$ Century Webster's International Encyclopedia. $1^{\text {st }}$ ed. Naples, FL: Trident Press International. Guest G. (1980). The March of Civilization. Ibadan: Spectrum Books Ltd.

[3] Goodrum, A.L. (2006). Cited in Dawson and Soames (2006) (above). Gunter, H. (1996). Cited in Dawson and Soames (2006) (above), p.184.

[4] Hornby, A.S. and Gowie, A.P. (1981) (eds). Oxford Advanced Learners Dictionary of Current English. Oxford: Oxford University.

[5] Lock, R. (1995). Cited in Dawson and Soames (2006) (above), p.184.

[6] Lock, R. and Miles, C. (1993). Cited in Dawson and Soames (2006) (above), p.184.

[7] Millar, W. (1996). Cited in Dawson and Soames Christiana (2006) (above), p.183-198.

[8] Nworgu, B.G (2006). Educational Research: Basic Issues and Methodology. $2^{\text {nd }}$ ed. Nsukka: University Trust.

[9] Signh, S.S., Gupta, P. and Gupta, A.K. (2006). Handbook of Agricultural Sciences. New Delhi: Kalyhani Publishers.

[10] United Nations (1992). Convention on Biological Diversity. Article 2: Use of Terms. http://www.cbd.int/convention/articles/?a=cbd. 02. Retrieved $6^{\text {th }}$ February 2008.

[11]Wikipedia (2009): The Free Encyclopedia (Biota: Biological Classification Domain and Kingdoms http://en.wikipedia.org/wiki/Biological-classification 